\title{
Reproductive Behaviour of Funambulus Pennatii A Case Study of Ajmer Rajasthan
}

\author{
Dr Rashmi Sharma \\ Department Of Zoology, SPC GCA Ajmer, Rajasthan, India
}

\begin{abstract}
Northern Palm Squirrel Funambulus Pennatii Is Native To India, Iran, Nepal, Pakistan, and Afghanistan. Adult Body Weight Is About $147 \mathrm{Gm}$; Body Length Ranges 230-356mm Including Tail. The Tail Alone Makes About Half of the Total Body Length. Key Physical Features Stripes On The Back, There Are Five Lightly Coloured Stripes On The Back. The Top Coat Color Is Grey. Head Is Also Grey. Widespread And Flexible In Their Habitat Preferences, Typically Living In Elevations Below 4000m. These Animals Have Been Found In Grass Land, Scrubland, Plantations, Dry Deciduous Forest, Urban, Rural, Suburban, Agriculture. Live On Plantation And Around Farm Lands And Near Houses. Play Role in Pollination and Dispersal of Plantation Trees. They Are Herbivorous To Omnivorous, They Typically Feed On Wide Variety Of Foods Seeds, Nuts, Buds, Young Bark, Leaves, Insects, Flowers And Grubs. They Also Eat Baby Birds. They Feed Both In Trees And On Ground. They Store Food For Later Use (Foraging Behavior). The Behavior Of Funambulus Pennantii Is Studied In Present Paper.
\end{abstract}

Classification

\section{Introduction}

$\begin{array}{ll}\text { Kingdom } & \text { Animalia } \\ \text { Phylum } & \text { Chordata } \\ \text { Class } & \text { Mammalia } \\ \text { Order } & \text { Rodentia } \\ \text { Family } & \text { Sciuridae } \\ \text { Genus } & \text { Funambulus } \\ \text { Sub genus } & \text { Prasadsciurus }\end{array}$

Moore and Tate $1965(2)$

Species Funambulus pennantii

They are quick, lithe, little animals with moderately bushy tails, big inquisitive eyes. A pattern of contrasting stripes running down the back. The five striped palm squirrel have five narrow beige stripes on a brown background. The outermost stripes are on the flanks and bordered below by a beige coat colour barely distinguishable from the stripes. Limbs tail and head are spectacled by light brown under parts are even lighter. It utters surprisingly loud, shrill trilling call when least alarmed and when encountering conspecifics. It is most commonly seen mammal in Ajmer. Diurnal, is found in drier areas.

Town and village dweller and often seen scurrying up and down trees and walls entirely at home in the midst of people and traffic and eating nut, fruit, bud or bark of tree. The female brings up the family alone in an untidy nest of grass leaves and cotton build in the rafters of house or in the trees. Young are born naked and blind and stay in nest until they can forage for themselves, female's only toleraye males in their vicinity during mating.

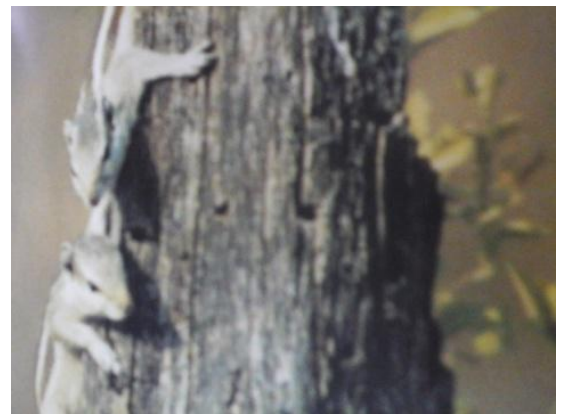

Nothern Palm Squirrel Funambulus pinnanti 
Northern Palm squirrel Funambulus pennatii is native to India, Iran, Nepal, Pakistan, Afganistan. Adult body weight is about $147 \mathrm{gm}$, Body length ranges $230-356 \mathrm{~mm}$ including tail. The tail alone makes about half of the total body length. Key physical features stripes on the back, there are five lightly coloured stripes on the back. The top coat colour is grey. Head is also grey. Widespread and flexible in their habitat preferences, Typically living in elevations below $4000 \mathrm{~m}$. These animals have been found in grass land, scrubland, Plantations, dry deciduous forest, urban, rural, suburban, agriculture. Live on plantation and around farm lands and near houses.

So they can be pest eating buds and seeds of food producing plants. Squirrel have liking for plants like neem (Azadirecta indica), Jamun, aam, Amrood, and play role in pollination and dispersal of plantation trees. It has also been introduced to Australia where it is found in Perth.(West Australia). In India southern boundry of the species is not clearly identified it may extend as far as Madanpalli. Southern boundry on Western Ghats sides clearly extends to localities including Dhawar and Mysore in Karnataka. They are herbivorous to omnivorous, They typically feed on wide variety of foods seeds, nuts, buds, young bark, leaves, insects, flowers and grubs. They also eat baby birds. They feed both in trees and on ground. They store food for later use (Foraging behavior). They play important role in spread of seeds. They also pollinate some plants. They provide food for birds of prey. Eagles and crows are predators of these squirrels. They use sight, touch, smell and acoustics to perceive their environment. They use sight Touch smell for finding food.Visual and sound displays are used in intraspecific communication. They are known for their repetitive shrill bird like calls. Perception channels are visual, tactile, acoustic and chemical.Diurnal and semiarboreal. Life expectancy is 6-7 years.

\section{Reproduction}

Squirrel are gregarious, upto 10 animals have been seen on one tree at a time. Multiple male fights over for 1 female. The dominant male then mates with female and leaves her within a couple of days. Breeding occurs several times a year with different partner each time.

Females have 2-3 litters yearly. Litter size ranges from 1-5. Female have gestation period of 40-45 days. Birth mass of newly born squirrel is 7 gms. Weaning period is 2 months. Male and female reaches sexual maturity 6-11 months. Male mature in 10 months and female mature in 8 months. Breed 2-3 times a year. Mating separated by 4-5 months. Most breeding occurs in March- April and July to September. Key reproductive feature is iteroparousie multiple reproductive cycles over the course of lifetime. Semelparous is single reproductive episode over the course of lifetime. Gonochorous / Dioecious 1 sex in 1 individual , Sexual fertilization , viviparous. Males does not show parental care and tend to leave the female within 1-2 days

After mating with her. Female build nest for youngones and nurses and protect them for 2 monthes.

\section{Conservation Status}

Squirrels are listed as least concern by IUCN Red list because of their wide distribution and ability to adapt to disturbed habitat. There is large population of squirrel in protected areas. And there is little threat to this species.

\section{Legislation}

India schedule IV of Indian wildlife Protection act 1972. Amended up to 2002.

\section{References}

[1]. Nameer, P.O. \& Molur (2008). Funambulus pennantii. (http://www.iucnredlist.org/details/8702/0) In; IUCN2012.IUCN Red List of Threatened Species. Version 2012.2. Downloaded on 03 June 2013.

[2]. Moore, J.C. And G.H.H. Tate (1965). "A study of Diurnal squirrels, Sciurinae, of Indian And Indo - Chinese subregions." Fieldiana Zoology 48: 1-351.

[3]. Wrought on, R.C. (1905). (The common striped palm squirrel.”) Journal of Bombay natural History Society 16; 406-413.

[4]. Thorington, R.W., jr.; Hoffmann, R.S. (2005). "Family Sciuridae. "In Wilson, D.E.; Reeder, D.M. Mammal species of the world: A taxonomic and geographic and geographic reference 3rd Ed. ). The Johns Hopkins University Press. Pp. 754-818. ISBN 0-8018-8221-4. OCLC 26158608.

[5]. Thorington, R.W., Jr. And R.S.Hoffman 92005). Family Sciuridae. Pp.754-818 in Mammal species Of the world a Taxonomic and Geographic Reference. D.E. Wilson and D.M. Reeder Eds. Johns And Hopkins University Press , Baltimore.

[6]. Ghose, R.K., Mandal, A.K. And Ghose, P.S. (2004). A contribution to the taxonomy of Indian Five striped squirrel Funambulus pennant, Wrought on), with description of two new Subspecies .Rec. zool.Surv.India, 102(3-4): 89-103.

[7]. Talmale, S.S. (2007). Studies on Small Mammal diversity in Maharashtra State. PhD. Thesis Submitted to university of Pane, Maharashtra State, India. 
[8]. Ellerman, J.R. (1961). The Fauna of India including Pakistan, Burma and Ceylon: Mammalia, Rodentia. Volume 3 (in 2 parts). Vol. 1: 1-482 \& Vol.2: 483-884. Second Ed. Zoological Survey of India Calcutta.

[9]. Srinivasulu C., S. Chakraborty and M.S.Pradhan (2004). Checklist of the Sciurids (Mammalia: Rodentia: Sciuridae)' (PDF). Zoos 'Print Journal 19 (2): 1351-1360. Doi; 10. 11609/jot.zpj.19.2.1351-60.

[10]. Long, J.L. (2003) Introduced Mammals of the world: Their history, Distribution and Influence. Csiro Publishing, Colingwood, Australia, ISBN 9780643099166.

[11]. Pradhan, M.S. And Kurup, G.U. (2001). Mammalia IN Fauna of Nilgiri Biosphere Reserve. Fauna of conservation area Series 11. Pub; Director, Zoological Survey of India, Kolkata;311-330.

[12]. Santharam, V. (2007). Five striped palm squirrel (Funambulus pennantii) in Rishi Valley, Chitoor district, Andhra Prasesh." A Bombay Natural History Society. 